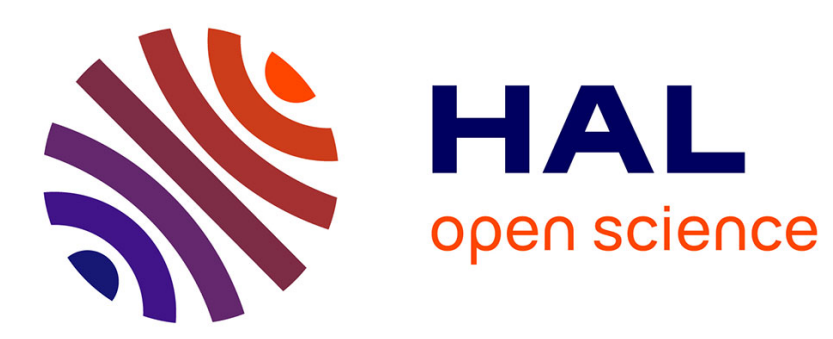

\title{
Frontier impedance effects and the growth of international exchanges: an empirical analysis for France Didier Plat, Charles Raux
}

\section{To cite this version:}

Didier Plat, Charles Raux. Frontier impedance effects and the growth of international exchanges: an empirical analysis for France. Papers in Regional Science, 1998, 77 (2), pp. 155-172. 10.1111/j.14355597.1998.tb00712.x . halshs-00144768

\section{HAL Id: halshs-00144768 \\ https://shs.hal.science/halshs-00144768}

Submitted on 24 Sep 2008

HAL is a multi-disciplinary open access archive for the deposit and dissemination of scientific research documents, whether they are published or not. The documents may come from teaching and research institutions in France or abroad, or from public or private research centers.
L'archive ouverte pluridisciplinaire HAL, est destinée au dépôt et à la diffusion de documents scientifiques de niveau recherche, publiés ou non, émanant des établissements d'enseignement et de recherche français ou étrangers, des laboratoires publics ou privés. 
Plat D., RauX C. Frontier impedance effects and the growth of international exchanges: an empirical analysis for France. Papers in Regional Science, 1998, vol. 77, n 2, pp. 155-172

\section{Frontier Impedance Effects and the Growth of International}

\section{Exchanges: An Empirical Analysis for France}

Didier PLAT, Charles RAUX

Laboratoire d'Economie des Transports (CNRS-Université Lumière Lyon 2-ENTPE)

Didier PLAT :

LET-ENTPE, rue Maurice Audin, 69518 Vaulx en Velin Cedex, France

(Tel : (33) 720470 47, Fax : (33) 720470 92, E-mail : didier.plat@entpe.fr)

Charles RAUX : (responsible for correspondence)

LET-MRASH, 14 avenue Berthelot, 69363 Lyon Cedex 07, France

(Tel : (33) 727264 03, Fax : (33) 727264 48, E-mail : Charles.Raux@let.mrash.fr) 
Abstract :

On the European Union scale, international traffic is growing faster than intra-national traffic. This phenomenon is often viewed as a consequence of the abatement of the "frontier-effect". In this paper we analyse the frontier effect, thanks to data available for road traffic between France and her neighbours and to freight transport data available at the EU level. The concept is discussed in the light of this empirical analysis. The shortcomings of the static approach lead to a critical reevaluation by the means of a longitudinal approach. In conclusion some potential directions for future research are discussed. 


\section{Frontier Impedance Effects and the Growth of International}

\section{Exchanges: An Empirical Analysis for France}

\section{INTRODUCTION}

There is little or no doubt that in the none too distant future there will be a significant increase in the level of international exchanges within the European continent. In the West, the development in life-styles, the ageing of the population, the ever-increasing and ever-morediversified offers made by tour operators, are all factors which lead to the splitting up of people's holiday periods and to an increase in the number of departures abroad (Portais, 1992). Multinational companies are slowly moving toward a division of work on a European Union scale, thanks to their strategy of take-overs and fusions (Szij, 1992). This brings about a reorganization of former commercial circuits and an increase in exchanges, whether it be goods or businessmen. In the East, the political opening-up has led to perspectives for an intensification in exchanges, and the beginnings are already perceptible. The number of tourists from central Europe coming to the West has thus passed from 25 million to 28 million between 1990 and 1992 (Reynaud \& al., 1993), while imports from ex-Iron Curtain countries increased by 25\% in 1991 (Foucher \& Potel, 1993). Even if the industrial structures or the purchasing power, which are still relatively weak, are liable to slow down the integration of the ex-socialist countries, all the conditions nevertheless seem to be present for an increase in flow-rates, unknown in the past.

Even though the relative proportion of international traffic seems still low, its acceleration on the transport networks is of special importance for several continental countries in Europe, at a crossroads of international land routes. This increase is worrying those who are in charge of 
road networks which have already reached the saturation point in many places, but also interests those in charge of the railways who are wondering about the profitability of international high-speed links. However, from a static point of view, flows on national relations are considerably higher than on international relations. This drop in cross-frontier traffic, when compared with national traffic, is usually referred to as a frontier impedance effect. One possible approach is then to analyze and modelize this frontier impedance effect, in order to evaluate the speed of its development (decrease, increase or stagnation) and consequently the development pace of international traffic.

Two major approaches exist in the literature for determining the impact of a frontier on the level of international exchanges. The first one can be referred to as global. It models spatial interactions between zones, which are usually of gravitational type, and tries to highlight the factors which determine the level of exchanges. Bröcker (1980), using the 1970 data on roadflow for goods between the 57 regions of the then six-member European Community, adjusts various models of loglinear interaction. He assimilates the frontier-effect to an extra cost in distance, which is added to the actual physical distance when the regions are in different countries. More recently, Bröcker and Rohweder (1990) focus on international trade, using a similar formulation to test the effects of various explaining variables (common border, colonial relations, membership of preference areas...). Such models are also used for studying other barriers to communication, differences in languages inside a country (Klaassen and al., 1972 ; Rossera, 1990), as well as international telephone calls (Rietveld \& Janssen, 1990).

The second approach, a more local one, tries to compare spatial relations among pairs of zones which are as similar as possible, one pair inside the state on the one hand, one pair across the frontier on the other hand. The frontier impedance factor appears when the traffic on the international relation is plotted against the one on the corresponding domestic relation. Nüsser (1989) defines the frontier impedance factor by comparing national and international 
flows between pairs of zones with almost identical characteristics as far as transport time, population and GNP are concerned. Despite insufficient data (lack of enough paired zones with available traffic data between them), an estimation can be made: on average, the existence of a frontier in 1982 divided passenger traffic by 4.7, where all other factors are taken as being equal (between Germany, Belgium, France, Luxemburg and The Netherlands). Whatever the approach may be, it is theoretically possible to reason by type of flow, either for a given purpose or a given merchandise, or for a given means of transport, or, on the contrary, to take all the exchanges in a zone into account. The analysis of international exchanges actually depends on the nature and the quality of the data available.

A rapid assessment of the available data enables us to come back to the two different approaches to the frontier effect which we referred to as existing in the literature. As far as the transport of persons is concerned, the sources are incomplete for both origins and destinations. It is therefore coherent for us to deal with local approaches, if we want to compare internal and international flows. In the case of the freight transport, the availability of inter-state exchange matrices leads us to examine things globally, all the more because the data cannot be disaggregated spatially. Furthermore, it is essential to model in order to limit the consequences of this rough spatial dividing-up.

Consequently, the aim of this paper is to analyse the frontier impedance effect, thanks to data available for road traffic between France and her neighbours (section 2), and also to freight transport data available at the EU level (section 3). In the last section, we discuss the concept in the light of this empirical analysis. 


\section{PASSENGER TRAFFIC AT FRONTIERS}

\section{A Difficult Measurement and a Road Supremacy.}

If the figures concerning public transport by rail and air are reasonably well known, the same is not at all true for individual road transport. The efforts to standardize and produce data at European level proposed by COST 305 (Fabre et al., 1988) have not yet given useable results. The range of available data is simultaneously limited and reasonably rich.

This range of data is no more than data about inter-EU (European Union) state movements in both directions, as far as rail and air traffic are concerned (EUROSTAT, 1991). This is not yet the case for road traffic. Given the impossibility of conducting costly surveys on road traffic origin-destinations, the only source of data available within the scope of this study were systematic traffic counts in both directions along French roads and motorways, and especially on sections just before the border line (SETRA, 1982 - 1992). These counts do not inform us about the origins and destinations of the vehicles, and this is a very severe limitation. However they are rich because of their systematic character, since they are carried out regularly at border crossing points. They thus have the advantage of taking everything that crosses the frontier into account and of giving the chronology for the last ten years. This is a specially interesting advantage for those who want to highlight the trends in international exchanges.

These various types of data are therefore not homogeneous from one mode to another. However, the comparison of the estimation of traffic per mode for the last common year available (1987) is instructive (Table 1). Whatever the real value of the number of road passengers may be - using an average vehicle occupancy rate of 1.5 to 1.9 (given by some specific surveys, Association Grand Sud et alii, 1989) - the road mode predominates. This 
importance of road in international passenger traffic leads us to focus the analysis on this mode, because it is probably there that the major influence of the frontier-effect is to be found, quantitatively speaking. Because these road data were only available for France, we also focus the analysis of international road passenger traffic on this country and its neighbours.

Table 1 : Annual passenger traffic (rail and air) and road traffic at frontiers between France and her neighbours (1987)

\begin{tabular}{|l|c|c|c|}
\cline { 2 - 4 } & $\begin{array}{c}\text { Rail } \\
\text { (in thousands of } \\
\text { passengers) }\end{array}$ & $\begin{array}{c}\text { Air } \\
\text { (in thousands of } \\
\text { passengers) }\end{array}$ & $\begin{array}{c}\text { Road } \\
\text { (in thousands of } \\
\text { vehicles crossing the } \\
\text { frontier) }\end{array}$ \\
\hline Italy & 3,443 & 2,098 & 11,899 \\
\hline Spain & 1,069 & 1,572 & 19,600 \\
\hline FRG & $1,986^{\mathrm{a}}$ & 1,780 & 38,970 \\
\hline Switzerland & - & 1,331 & 28,833 \\
\hline Belgium & 2,025 & 495 & $31,536^{\mathrm{b}}$ \\
\hline GB & 1,108 & 4,371 & $15,947^{\mathrm{c}}$ \\
\hline
\end{tabular}

a In 1988

$b$ Count limited to major roads (value by default)

c Maritime passenger traffic between French and British ports

Sources: EUROSTAT for rail and air figures, traffic counts evaluated by the authors from data of SETRA and CETE (Department of Transport) for road traffic.

But we must then speak of trans-frontier traffic and of internal traffic, since the origins and destinations of the road traffic are generally not known. However international transit would not seem to be of considerable importance in trans-frontier traffic, even if the quantitative data for it is not well-known. International transit is around 5\% to $10 \%$ of transfrontier traffic at the German border in 1987 (CETE de l'Est, 1989) and less than 10\% in 1989 on the French Riviera Motorway at the Italian border (Association Grand Sud et al.,1989). 
From Drops In Traffic To Frontier Impedance Effects?

The classical approach would consist in setting up a sample of links and model the frontier impedance effect, with traffic generators estimated at each end of the links. This approach is somewhat easy for rail or air traffic as data include origins and destinations. Because of the lack of precision in the road data mentioned before, we cannot use this approach. However we can try to extract as much as possible information from these road counts series.

We can first give some evidence of the drop in traffic by comparing traffic in the close neighbourhood of the border with internal traffic on the same link. The chosen links are firstly those where the internal long distance traffic is concentrated. This is why we selected interurban motorways, which are mostly tolled in France with distant intersections (generally more than $10 \mathrm{~km}$ ), so we avoid most of the local urban traffic. Furthermore we chose internal locations distant from urban agglomerations to ignore traffic concerned by exchanges within these areas. These motorways are also those where the transfrontier traffic is concentrated, given the geophysical configuration of the border. For each of them we compared the traffic coming up to the frontier (trans-frontier traffic) with the traffic observed on the same motorway within France (internal traffic). The data has been obtained from counts carried out in 1990 (SETRA, 1992) unless otherwise specified. The links are described below (see map Figure 1 and Table 2) :

- Frontier between France and Belgium : the internal traffic counts are taken (a) on motorway A1 in the south of Lille which is the main link of exchanges between Lille conurbation and parisian region but is also concentrating international traffic between France and northern Europe, (b) on motorway A25 and A23 for exchanges with respectively West and East of Lille. The transfrontier traffic is measured with the aggregation of traffic on A22 and A27, which are the links between Lille 
conurbation and Gent and Brussels. The drop in traffic is estimated by default, by comparison with A1 to avoid redundant counts of traffic on A25 and A23, at a level of 1.7 .

- Frontier between France and Italy : the internal traffic counts are taken on motorway A7 at the Lançon toll gate, 30km north from Marseille, which concentrates simultaneously exchanges between firstly Rhône Valley and rest of France in the north, secondly South West of France and thirdly Provence-Côte d'Azur in the south-east. The transfrontier traffic is measured on motorway A8 at La Turbie, the last tollgate near the frontier with Italy : at this place A8 traffic includes local traffic with Menton and Monaco and transit traffic with Italy. The drop in traffic is estimated at 3.0.

- Frontier between France and Spain : two links are considered, on the Mediterranean coast on motorway A9 and on the Atlantic coast on A63. On A9 the internal traffic counts are measured at the tollgate $10 \mathrm{~km}$ south from Montpellier, where is concentrated the long distance traffic between firstly Rhône Valley and rest of France in the north, secondly Provence-Côte d'Azur in the east and thirdly South West of France and Spain in the south. The transfrontier traffic is measured at the Perthus tollgate where the only traffic is transit with Spain. The drop in traffic on A9 is estimated at 2.6. On A63 the internal traffic is measured near Bayonne where counts include exchanges between the Bayonne-Biarritz conurbation and the whole south-west region ; the transfrontier traffic is taken at Biriatou tollgate at the Spanish frontier. The drop in traffic on A63 is estimated at 1.8. 
Table 2 : Comparison of internal and trans-frontier traffic (in vehicles/day)

\begin{tabular}{|c|c|c|c|c|c|c|}
\hline \multirow{2}{*}{$\begin{array}{l}\text { Road traffic } \\
\text { France/Belgium }^{\mathrm{a}}\end{array}$} & \multicolumn{2}{|l|}{ Internal } & \multicolumn{2}{|l|}{ Trans-frontier } & \multicolumn{2}{|l|}{ Drop in traffic } \\
\hline & A1 South Lille & 63,900 & A22 North Lille & 28,000 & $\mathrm{~A} 1 /(\mathrm{A} 22+\mathrm{A} 27)$ & 1.7 \\
\hline & A23 East Lille & 26,500 & A27 North Lille & 9,100 & & \\
\hline & A25 West Lille & 31,600 & & & & \\
\hline France/Italy $^{\mathrm{b}}$ & A7 Lançon & 40,150 & A8 La Turbie & 13,350 & A7/A8 & 3.0 \\
\hline France/Spain $^{\mathrm{b}}$ & A9 Montpellier 2 & 28,450 & A9 Le Perthus & 10,800 & Montp./Le Perthus & 2.6 \\
\hline c & A63 Bayonne & 18,982 & A63 Biriatou & 10,410 & Bayonne/Biriatou & 1.8 \\
\hline
\end{tabular}




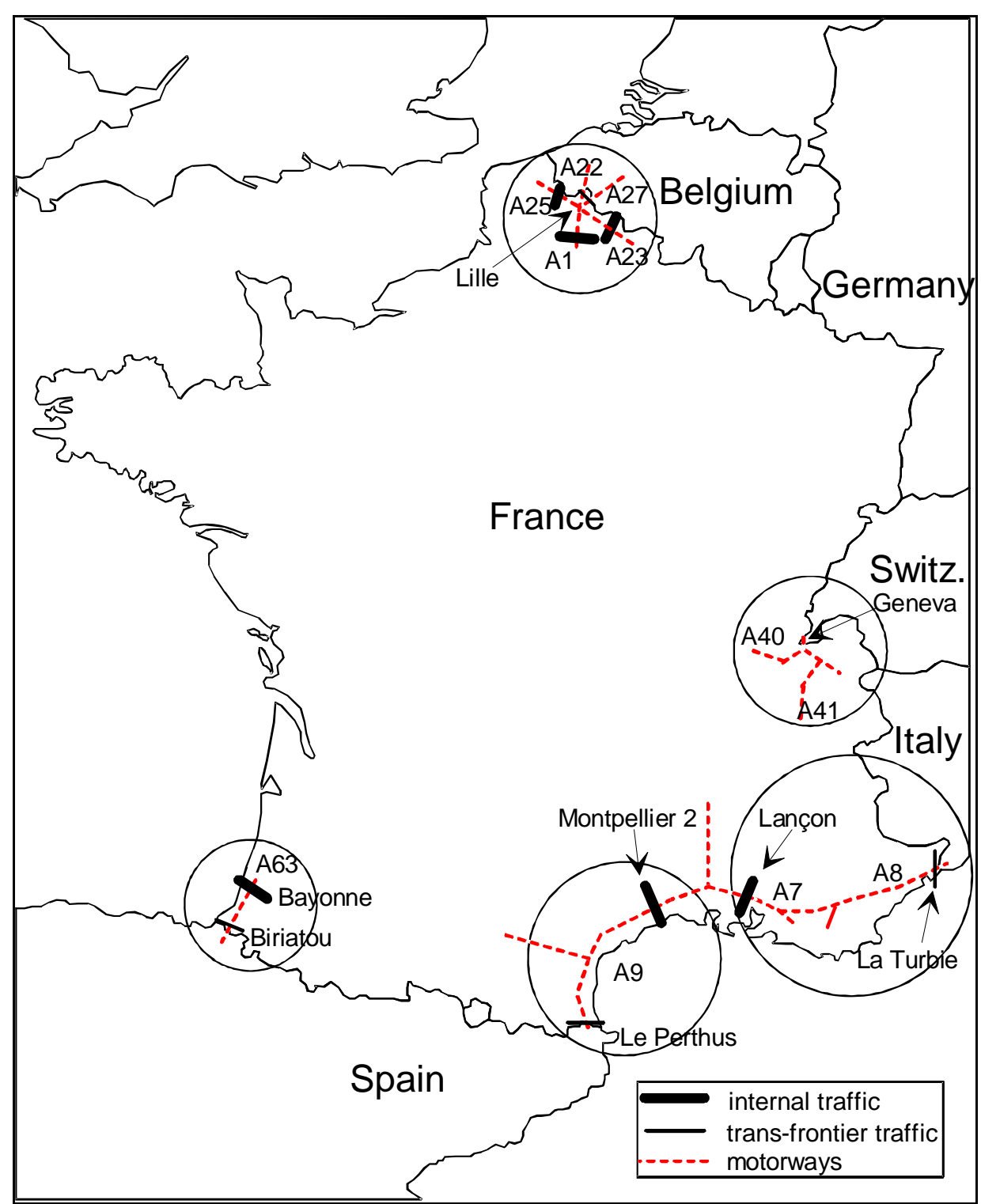

Figure 1: Areas used for comparison between internal and transfrontier traffic

For the transfrontier traffic between France and Germany, this analysis is more difficult because of the geophysical configuration of the Alsace plain which allows numerous links of border crossing between the two countries. The case of traffic with Switzerland, especially complex in the region of Geneva, is commented below.

These comparisons of internal traffic and transfrontier traffic on carefully chosen links, show consistent measures of drop in traffic, varying from 1.7 to 3 . However, when available, more detailed data can help to specify the frontier-effect. This the case for the traffic counts on A7 
and A8 at the Italian frontier as origins and destinations categories can be computed (from Association Grand Sud et al., 1989). We can distinguish four traffic categories : exchanges within the region (less than $200 \mathrm{~km}$ ) named « intra-regional », exchanges with other French regions named « inter-regional France », exchanges with Italy named « inter-regional Italy », transit from or to Italy. The intra-regional category scores nearly identically in both case, 31\% at Lançon and 39\% at La Turbie (Table 3). However the locations of these two nodes yield different interpretations of inter-regional categories :

- in the Lançon A7 case, the «inter-regional France » traffic category is responsible mainly to medium distance inter-regional traffic (60\%, including $13 \%$ with other southern French regions and $47 \%$ with the Rhone Valley and the north); on the opposite the inter-regional Italy category includes mainly long-distance traffic as the Italian frontier is more than $400 \mathrm{~km}$ away from there.

- in the La Turbie/A8 case the medium distance inter-regional traffic is given by the category inter-regional Italy while the inter-regional France category is responsible to long distance traffic, as Marseilles and the Rhone Valley are more than $400 \mathrm{~km}$ away from the border.

Thus we observe a medium distance inter-regional traffic whose share is $60 \%$ at Lançon, without any frontier, and $46 \%$ at La Turbie, with a frontier. If we consider this flow category, which is the only one concerned by the frontier, then the frontier effect would be only 1.3 (60/46). 
Table 3: Traffic categories by origins-destinations at Lançon and La Turbie

\begin{tabular}{|l|c|c|}
\cline { 2 - 3 } \multicolumn{1}{c|}{} & Lançon A7 & La Turbie A8 / Italy \\
\hline Intra-regional & $31 \%$ & $39 \%$ \\
\hline Inter-regional France & $60 \%$ & $5 \%$ \\
\hline Inter-regional Italy & $5 \%$ & $46 \%$ \\
\hline Transit with Italy & $4 \%$ & $10 \%$ \\
\hline Total & $100 \%$ & $100 \%$ \\
\hline
\end{tabular}

Further, if we use this method as regards the Swiss frontier with France, in the region of Geneva, the comparison is more complex because of the lay-out of the network and the overlapping of the A40/A41 motorways with the trunk roads which can all be used as crossing points from France to the Geneva conurbation. Moreover the traffic measured between Gex, Ferney-Voltaire, in the French frontier zone, and the Swiss frontier (approx. 12,500 vehicles/day in 1988) compared with the preceding road section of the same trunk road in France (2,500 vehicles/day) shows that the frontier-effect has been reversed. In this case, we could almost speak of a frontier effect between the French frontier zone and the rest of France.

This can of course be explained by the number of exchanges between the French frontier zone and Geneva, and the geophysical layout of this region, specially that of the High-Jura which forms a barrier to liaisons with zones farther inside France. This flow at the Swiss/French border is typical of a phenomenon of daily cross-frontier migrations for work purposes. This phenomenon can also be observed along the French/German border : out of all the Alsace border posts, $74 \%$ of the light vehicle traffic is to be found within a radius of $25 \mathrm{~km}$ of the frontier post (CETE de l'Est, 1989). The same phenomenon can only be suspected along the Belgian and Italian Riviera frontiers, since detailed statistics are not available. 
To sum up, drops in traffic counts on motorways are identified which could be linked up to the presence of a frontier. But this method yields also another type of frontier, this one not an inter-state frontier but rather an economic one.

This method of comparing trans-frontier traffic with internal traffic is therefore somewhat questionable, even if it gives similar results in certain cases. First of all, we have seen the difficulty, as far as road traffic is concerned - but we must deal with it -, in clearly identifying and separating international exchange traffic from domestic traffic. Further, even if we could measure the international exchange flow, thanks to a new effort in gathering adhoc data, how can we decide which theoretical flow to compare it with? This notion of theoretical flow refers to a situation in which there would be no frontier - this would be a mythical and atemporal situation projected into the present. This conception contradicts the historical process which has contributed to the formation of inter-state frontiers and which is to be seen in international exchanges. This is why we propose a longitudinal approach for the frontier effect, which would seem more promising when we are faced with the methodological difficulties which we have just brought up.

Does Road Traffic Grow More Rapidly At Frontiers Than French Internal Traffic ?

The second approach to the frontier effect is dealt with in the following manner : if, using chronological series, a growth differential is highlighted in which internal traffic grows more slowly than international one, we can then see a reduction in the frontier effect. The measurement here is no longer expressed in absolute terms as in the preceding section, but rather in relative terms.

The development of traffic inside France is represented by two indexes of road traffic (Department of Transport). One of them concerns traffic on the whole trunk road network (both roads and motorways), and the other deals with traffic on part of the network only - the 
inter-city motorways, which are mainly tolled. These traffic indexes are based on the observation of a panel of traffic counts which are representative of the network.

We have been able to reconstitute the chronology of the traffic at certain frontiers by totalling the traffic on roads and motorways at border crossing points. This was relatively simple along the Italian and Spanish frontiers between 1982 and 1992 (SETRA, 1982 - 1992), taking into consideration the limited number of road crossings permitted by the mountain barriers. The geophysical configuration of the French/Belgium border and the complexity of the liaisons along the France/Switzerland border makes it very difficult to carry out this systematic reconstitution. On the other hand, specific studies for the Alsace plain make this possible for the French/German border between 1982 and 1987, but with a discrepancy in traffic counts in 1985 (CETE de l'Est, 1991). 


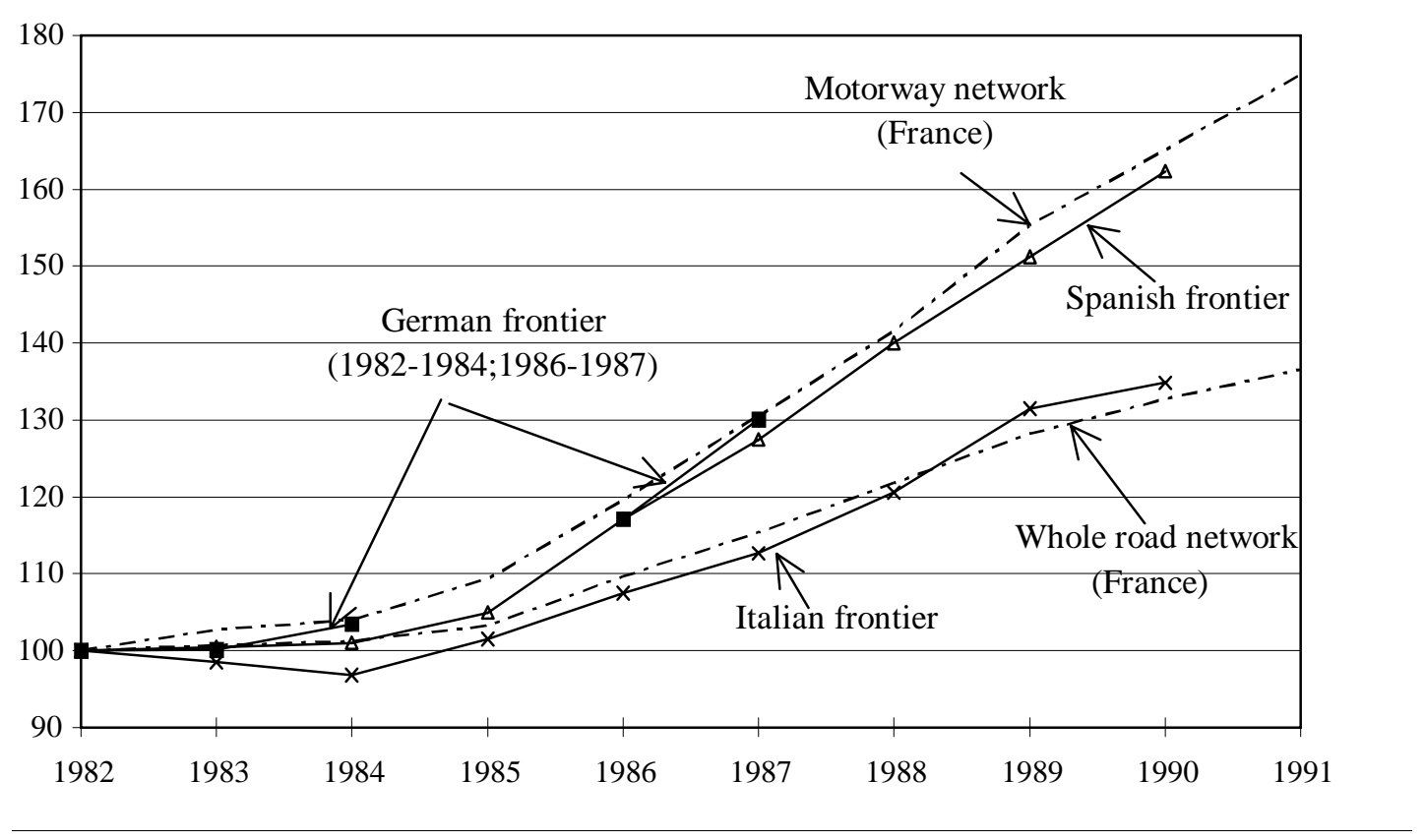

Figure 2: Development of frontier traffic compared with indexes of internal traffic (basis 100 in 1982)

The rise in traffic over the whole of the French network (Figure 2) has been continuous and picked up after 1985. However the growth in traffic is even greater on motorways. This growth of road traffic on the French network would appear to be encouraged by the traffic on motorways. These growth and traffic concentration on motorways can be seen as a consequence of the considerable investments made in France to extend and improve the motorway network.

What can then be said about frontier traffic? As far as Germany is concerned (up to 1987), the traffic at the frontier increased more than the French total internal traffic, and this was at the same pace as internal motorway traffic. The traffic at the Italian frontier progresses at the same pace as total internal traffic in France, and this means that the drop factor due to the frontier remains constant during this time. However, inside the total traffic at the 
French/Italian border, the traffic on the A8 motorway on the Riviera (Menton), is increasing rapidly : this growth is at the same pace as that of the flow indicator for French motorways.

For Spain we can see (Table 4) a considerable growth of the traffic at the frontier from 1985 onwards. It is to be remembered that 1985 is the year in which the treaty enabling Spain and Portugal to join the EEC was signed. This acceleration was preceded by an acceleration in the internal traffic along the A9 motorway between Montpellier and Béziers, and it perfectly follows the development of traffic on the motorways.

However, a more detailed examination of the traffic at the Spanish frontier shows that the share of traffic at the French/Spanish border on the motorways only, i.e. the Mediterranean Coast A9 Motorway and the Atlantic Coast A63 Motorway, goes from 42\% of the total in 1982 to $48 \%$ in 1990 . Even if the increase in traffic from France to Spain (62\%) is correctly reflected by that of the traffic on French motorways, the increase in this traffic at the frontier is also to be seen locally along the trunk roads. It therefore looks as if the improvement in motorway supply on the whole French network over recent years has promoted an increase in the French/Spanish border traffic not only on the motorways, but also on the trunk roads. 
Table 4 : Mean annual daily traffic at the main border crossing points

between France and Spain (in veh/day)

\begin{tabular}{|l|r|r|r|r|r|r|r|r|r|}
\hline SPAIN & 1982 & 1983 & 1984 & 1985 & 1986 & 1987 & 1988 & 1989 & 1990 \\
\hline A63 $^{\text {a }}$ (Atlantic) & 5373 & 5511 & 5267 & 5800 & 6550 & 7250 & 8450 & 9600 & 10410 \\
\hline Hendaye (RN 10$)$ & 7034 & 6824 & 6498 & 6900 & 7372 & 7553 & 8100 & $\mathrm{nc}$ & 9652 \\
\hline Fos (RN 125) & 1531 & 1626 & 1687 & 1645 & 1687 & 2020 & 2100 & $\mathrm{nc}$ & 2283 \\
\hline Bourg-Madame Est (RN 116) & 2550 & 2412 & 2424 & 2928 & 3432 & 3151 & 4000 & $\mathrm{nc}$ & 5687 \\
\hline A9 (Méditerranée) & 8824 & 9074 & 9813 & 9450 & 10750 & 11850 & 12700 & 13400 & 14231 \\
\hline Cerbère (RN 114) & 2000 & 1983 & 1897 & 1929 & 2202 & 2978 & 2900 & $\mathrm{nc}$ & 2079 \\
\hline Total & 33687 & 31029 & 34100 & 34431 & 39057 & 42260 & 46050 & 48475 & 50899 \\
\hline Basis 100 in 1982 & 100 & 100 & 101 & 105 & 117 & 127 & 140 & 151 & 162 \\
\hline \% annual increase & - & $0,4 \%$ & $0,6 \%$ & $3,9 \%$ & $11,7 \%$ & $8,8 \%$ & $9,9 \%$ & $8,0 \%$ & $7,4 \%$ \\
\hline share for A9 and A63 & $42 \%$ & - & - & - & - & - & - & - & $48 \%$ \\
\hline A9 Montpellier-Béziers & 23290 & 24099 & 25140 & 26226 & $\mathrm{nc}$ & $\mathrm{nc}$ & 34500 & $\mathrm{nc}$ & 37663 \\
\hline Basis 100 in 1982 & 100 & 103 & 108 & 113 & $\mathrm{nc}$ & $\mathrm{nc}$ & 148 & $\mathrm{nc}$ & 162 \\
\hline
\end{tabular}

Source : SETRA. In italic print estimations or interpolations for 1989

${ }^{a}$ RN stands for "Route Nationale" that is trunk road, A stands for "Autoroute" that is motorway

\section{SURFACE FREIGHT TRANSPORT}

Concerning the data, the situation would at first sight appear more favourable for goods than for passengers. EUROSTAT (yearly) gives a data base for overland goods exchanges within the EU. This data deals with tonnes transported and tonnes-kilometers produced, whether it be by road, rail or waterways.

Its use, however, is limited by several factors. We must first note that countries are only required to produce statistics if they already belong to the EU - it is therefore impossible to obtain a long series for Spain and Portugal. Furthermore, the flow is only noted for EU vehicles. It is more or less satisfactory for exchanges between two member-countries, but not for exchanges between a member-country and a non-member-country. Moreover, statistics for 
air freight are not available and this is a rapidly expanding sector. It is nevertheless reasonable to think that this handicap is limited in so far as the approach per type of product is sufficiently well aggregated. More important, the available geographical scale yields some problems. Internal transport is divided up into regional statistics for a limited number of countries, either for reasons of size, or simply because the statistics are lacking. The levels of international exchanges can only be seen through inter-state flows. The maximum level of disaggregation for the construction of exchange matrices within the EU is the Nation-State. The areas and economic weights, i.e. the distances to be covered and the quantities to be transported, vary considerably from one European country to another. These differences have to be integrated into the analysis.

Out of the twelve initial members of the Union, only eight systematically supplied internal and international statistics for overland goods transport in tonnes and in tonnes $\mathrm{x}$ kilometers between 1982 and 1990. These countries were: Germany, France, The Netherlands, Belgium, The United Kingdom, Ireland, Denmark and Greece. Compared with the whole traffic within and between these eight countries, less than one ton in twenty crosses the frontiers of any of these countries, but this low proportion masks a higher growth differentials with intranational traffic. Nevertheless, the information which is lacking will not prevent us from using the statistics, since the potentiality for global transport is unequally divided out within the EU (Figure 3). From the point of view of national transport, five of the eight countries, Germany, France, The Netherlands, Belgium and the United Kingdom count for 95\% of the overland tonnage transported inside each of the eight countries. As far as international transport is concerned, the first four either receive or send 95\% of the tonnage exchanged by the eight. If the four countries which are partially or completely missing from Eurostat (Spain, Italy, Luxemburg, Portugal) were taken into account as well, nothing would change radically. Concerning international transport, Germany, The Netherlands, Belgium and France will still 
concentrate 85\% of the tonnage transported (Diaz Olvera et alii, 1995). At European Union scale, the international flow of goods is spatially highly concentrated and we will now focuse on the exchanges between these four countries.

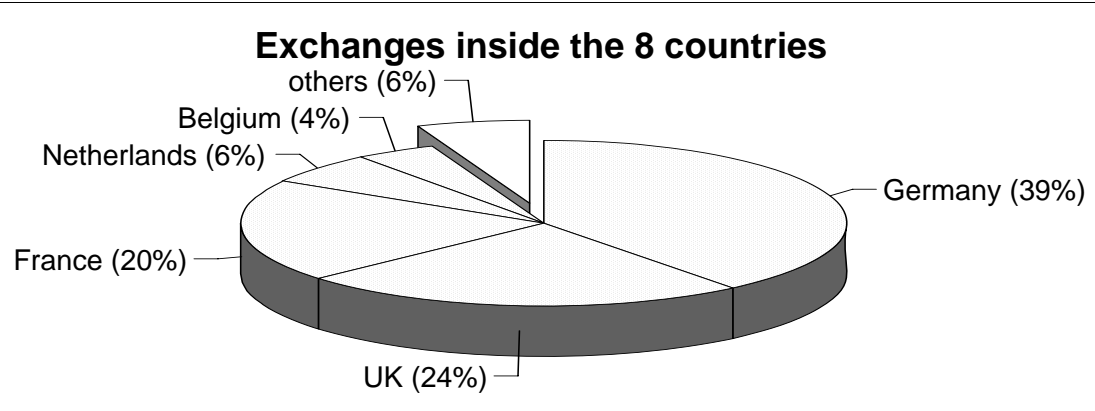

Exchanges between the 8 countries

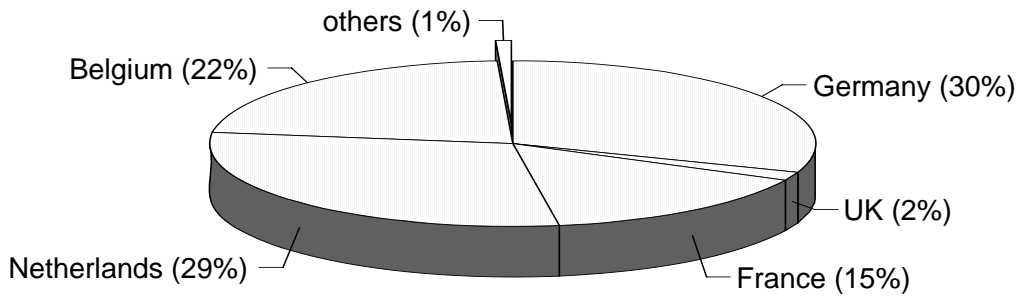

Figure 3 : Relative shares for different countries of the total traffic inside each of the eight countries (top) and of traffic between these eight countries (bottom)

\section{Models specification}

For the overland transport of goods, the basic material is a set of nine $4 \times 4$ matrix representing, for the years 1982-1990, the exchanges between Germany, Belgium, France and The Netherlands.

In the perspective of the analysis of frontier effect, we must deal more with the relative importance of the exchanges rather than with their volume. In other terms, we have to separate the determining of the structure of the exchanges from their volume, and concentrate 
only on the structure. So, we are in the same case as Savage \& Deutsch (1960) when they designed their « null model »: we try to observe the deviation between observed flows and exchanges resulting of a situation of independence of the places of origin and destination of goods. It looks unnecessary to try to catch the effect of the size of regions of origin and destination, using the usual balancing factors, and more appropriate to compare directly the observed flows to the flows calculated for the independence situation.

Let assume the following notations :

$T_{i j}^{t}$, for $i<>j$

tonnage transported during the year $t$ by road, rail and waterways from country $i$ to country $j$ (source : EUROSTAT);

$T_{i i}^{t}$ exchanges (in tons) within country $i$;

Dist $_{i j}$ mean distance (in kilometers) calculated between $i$ and $j$, calculated as ratio of tons-kilometers produced and tons transported ;

Front $t_{i j}^{t}$ frontier effect between country $i$ et $j$ for the year $t$, with restrictions Front $_{i j}^{t}=$ Front $_{j i}^{t}, \forall i j$ and Front $t_{i i}^{t}=0, \forall i, \forall t ;$

$I_{i j}^{t}$ tonnage transported in the independence situation. Its value is easy to calculate $: I_{i j}^{t}=\frac{\sum_{i} T_{i j}^{t} \cdot \sum_{j} T_{i j}^{t}}{\sum_{i} \sum_{j} T_{i j}^{t}}$.

The model chosen is a specific case of the log-linear model of inter-regional flows (Bröcker, 1980) which can be written :

$T_{i j}^{t}=I_{i j}^{t} \cdot \exp \left(\beta+\chi \cdot\right.$ Dist $_{i j}+$ Front $\left._{i j}^{t}+\varepsilon_{i j}^{t}\right)$

where $\beta$ and $\chi$ are parameters to be estimated, $\varepsilon_{i j}^{t}$ the error term, with i.i.d. $\varepsilon_{i j}^{t}$. An alternative specification $\varepsilon_{i j}^{t}=\eta_{i j}+\mu_{i j}^{t}$, with i.i.d. $\eta_{i j}$ and i.i.d. $\mu_{i j}^{t}$, would allow for spatial and 
temporal autocorrelation : however the estimation of such a complex model is beyond the purpose of the study, which is to estimate orders of magnitude of frontier effect. The frontier effect appear as a « sudden increase » (Nijkamp \& al, 1990) in the cost of communication and can be expressed as an extra-distance (equal to Front $_{i j}^{t} / \chi$ ).

Four sets of restrictions were tested :

- Front $_{i j}^{t}=0, \forall i, j$ and $\forall t$

- Front $_{i j}^{t}=$ Front, $\forall i, j$ and $\forall t$

- Front $_{i j}^{t}=$ Front $_{i j}, \forall t$

- Front $_{i j}^{t}=$ Front $^{t}, \forall i, j$
(Model I)

(Model II)

(Model III)

(Model IV)

The first model reflects a situation without frontier effect. The second one considers a frontier effect constant in time and space, when the third one is time-constant and space-variable and the fourth one space-constant and time-variable. With all other parameters unchanged, the crossing of a frontier then corresponds to a reduction in the tonnage transported at international level compared with the total tonnage sent or received, the factor of reduction being $\exp \left(-\right.$ Front $\left._{i j}^{t}\right)$.

The estimation technique used is OLS, after dividing equation (1) by $I_{i j}^{t}$ and after a logarithmic transformation of the result. While distance and the crossing of a frontier penalizes exchanges, the estimates of $\chi$ and Front $t_{i j}^{t}$ are expected to have negative signs.

\section{Main results}

From one pair of countries $(i, j)$ to another, the value of the ratio $\frac{T_{i j}^{t}}{I_{i j}^{t}}=R_{i j}^{t}$ strongly differ. We must first note (Table 5) that for 1990, the internal coefficients (on the diagonal) are all over one, whereas the international ones are always less than one. This situation reflects the net 
predominance of internal exchanges over international flows, the size of the difference varying from one country to another. On the international side, the Belgium/Netherlands pair gives values which are considerably higher than those of the other international exchanges and moreover they are close to one. This phenomenon can be explained by the fact that these two countries have been integrated into the Benelux unit for many years now.

$\underline{\text { Table } 5 \text { : Ratios }} T_{i j}^{t} / I_{i j}^{t}$ for the year 1990

\begin{tabular}{|l|c|c|c|c|}
\hline $\begin{array}{l}\text { Towards : } \\
\text { From : }\end{array}$ & Germany & Belgium & France & Netherlands \\
\hline Germany & 1.766 & 0.111 & 0.026 & 0.143 \\
\hline Belgium & 0.110 & 10.736 & 0.271 & 0.795 \\
\hline France & 0.030 & 0.172 & 3.455 & 0.046 \\
\hline Netherlands & 0.289 & 0.993 & 0.071 & 7.676 \\
\hline
\end{tabular}

During the period 1982-1990, the ratios show considerably contrasting and even erratic developments. Their stability from one year to another is tested by adjusting for each country elementary models of the following form :

$$
R_{i j}^{t}=\alpha \cdot R_{i j}^{t-1}
$$

The estimation obtained is systematically of a high statistical quality ( $\mathrm{R}^{2}$ around 0.99 whatever the adjustment base may be). For intra-state traffic for the four countries, as well as German international traffic, however, parameter $\alpha$ is not significantly different from 1 , so we cannot eliminate the hypothesis of the temporal stability of the ratios. On the other hand, the results obtained for the other three countries' international exchanges show a net growth for this factor : 3.4\% p.a. for Belgium, 3\% for The Netherlands, and 3.8\% for France. Over and above the annual fluctuations, we can see a much more clearly marked dynamic for international exchanges, which should then be reflected in a frontier effect's decrease. 
The estimation from Model I gives a high $\mathrm{R}^{2}$ adjusted (0.925) and leads to the equation

$$
T_{i j}^{t}=I_{i j}^{t} \cdot \exp \left(2.166-0.0125 D I S T_{i j}\right)
$$

(See detailed regression results in Appendix).

The integration of a constant frontier effect (Model II) slightly improves the $\mathrm{R}^{2}$ adjusted as compared with Model I (0.934 against 0.925) : introduction of constant frontier effect is highly significant, as shown by F-test (see Appendix). The handicap that is created by the crossing of a frontier is then estimated at a reduction of $50 \%$ of the exchanges, which is the mean value in time acording to the countries studied. This value is close to a frontier effect factor of two to three, measured for vehicle road traffic.

The introduction of a variable frontier-effect from link to link (Model III) is highly significant against Model II, as shown by F-test. The mean value of the handicap in Model II therefore hides considerable differences from one link to another, according to Model III. But the tratios for the constant and the distance and the estimates of these two parameters are lower than for the other models. The frontier effect is 2.5 times greater between France and Germany than it is between Belgium and The Netherlands (Figure 4). The Netherlands show lesser frontier-effects - notably because of the importance of the port of Rotterdam in international freight traffic - and its strongest relation is with Belgium, that is to say, inside Benelux. For France the strongest links are those it has had for a considerable length of time with Belgium. The links between France and Germany are weak, since the estimation of the frontier effect corresponds to a drop in traffic of around nine tenths. This result simply shows that, in view of the weight of internal exchanges in each of these two countries, their mutual integration via international freight exchanges is weak, particularly when compared with other countries of the sample. 


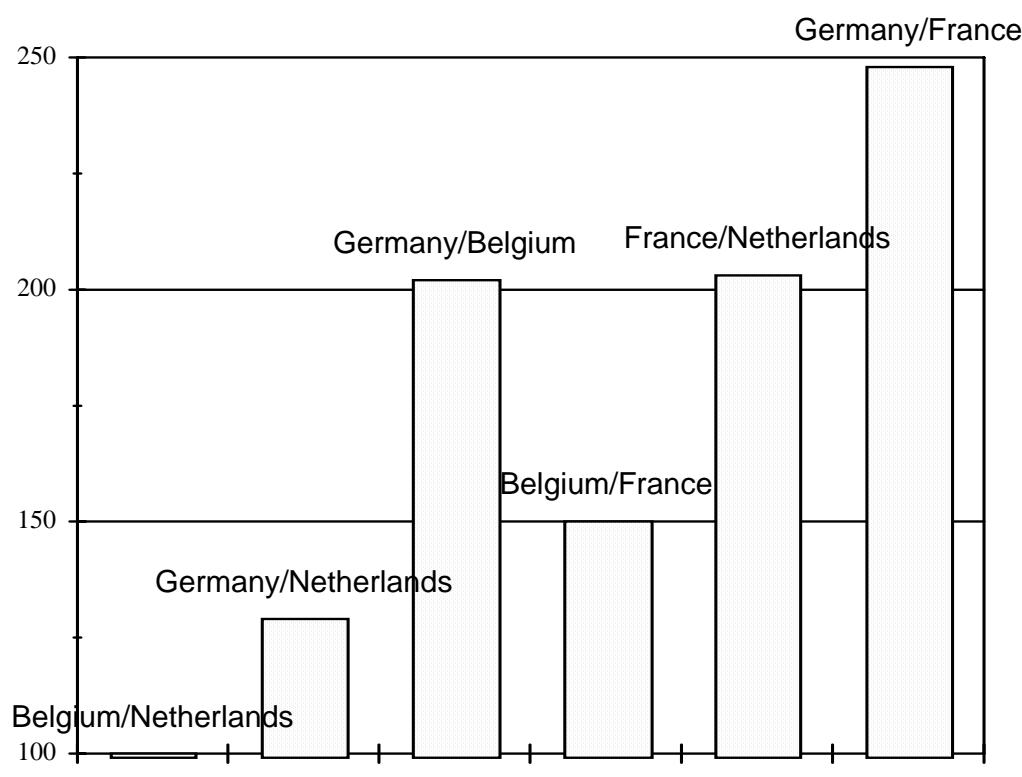

Figure 4 : Static structural frontier effects (relative values, basis 100 for

\section{Belgium/Netherlands)}

The introduction of a development of frontier effect (Model IV) against constant frontier effect (Model II) is not significant : our sample does not permit to conclude that frontier effect varies significantly during the period. The variation is irregular (less than $1 \%$ per year in average). The drop in traffic resulting from the crossing of the frontier stagnates between 1984 and 1988 (Table 6). In this case residuals are autocorrelated, suggesting that other specifications should be searched for if a prediction of frontier-effect development is needed.

Table 6 : Development in the drop in traffic due to the crossing of a frontier (\%)

\begin{tabular}{|l|c|c|c|c|c|c|c|c|c|}
\hline Years & 1982 & 1983 & 1984 & 1985 & 1986 & 1987 & 1988 & 1989 & 1990 \\
\hline Drop in traffic & 54.3 & 51.3 & 50.2 & 49.5 & 49.7 & 49.9 & 49.4 & 47.6 & 47.4 \\
\hline
\end{tabular}


Modelling goods exchanges between the EU four major countries (in terms of tons moved) yields estimates of frontier-effects. These effects are considerable and strike us by their size the traffic is divided by at least two. Estimations seem to converge between the local analysis of road traffic on the one hand and the global analysis of the exchange of goods on the other hand. But there is a significant amount of ambiguity in such a way of presenting the figures.

\section{CONCLUSION}

We have highlighted and sometimes estimated the drop in traffic due to the crossing of an inter-state frontier. But because of the choice of terminology it's easy to move rapidly from the acknowledgement of the statistical co-variation of two phenomena to the explicit affirmation of an analytical causality : "as the name indicates" - it is the frontier which creates the frontier effect - if we do away with the frontier, we do away with the frontier effect.

If it is clear that the frontier can symbolize a whole set of differences between territories (administrative, linguistic, monetary, cultural etc.), it is also obvious that if the administrative frontier disappears, all these differences will not disappear with it.

First and foremost, the demand for transport cannot be analyzed without reference to the supply which is historically, physically and durably traced upon the soil -through networks of infrastructure with a centripetal logic, which penalize inter-state centrifugal relations (Rey, 1991). As we have seen, the improvement of the road supply thanks to the creation of veritable motorway networks in France, and the improvement of the interfaces across the borders has a double consequence:

- on the one hand, the increase in traffic in France, accompanied by a concentration on high-speed through roads, which can be seen in the development of the traffic flow index on motorways ; 
- on the other hand an encouragement for European companies and tourists, including French ones, to make use of the French and European connected networks.

The through-motorway supply is therefore liable to play an important role in the decrease of the frontier effect in the various European countries. The opening of a trans-frontier motorway link works in the same way as an opening which flows would rush into. But as the actual transport bottlenecks play a protectionist role at the national and local levels, it is not so easy to solve the European transport-related barrier problems (Maggi, 1994).

Second, we have to reconsider barriers to exchanges between the many varied economic and social systems, barriers which a simple reduction to the administrative dimension radically denatures. The example of the relations between Geneva and the surrounding countryside, whether we be dealing with France or Switzerland, show how permeable frontiers can really be, without speaking of intra-national "frontier" effects. There is no doubt that an inter-state frontier can be both the wall which it costs more to cross, and the wall of socio-economic differentiation which a frontier region can count on to help its development (Ratti, 1990 and 1991). There is no simple and indubitable relationship between flow and frontier : the frontier is the sometimes active, sometimes passive witness of the contradictory trends in the integration and autonomisation which goes on in national and transnational socio-economic systems.

As we have shown, a longitudinal analysis of international exchanges, compared with the internal exchanges in a country is liable to overcome the theoretical and methodological difficulties which we have highlighted. However, an aggregate approach to international transport flows appear to be illusory, since the underlying mechanisms are heterogeneous and antagonistic. The analysis must then try to point out the differentiated dynamisms of international exchanges. Some categories of exchange show up immediately : the flow of 
business and goods ; the international tourist trade ; trans-frontier exchanges etc. But none of these has ever been systematically analysed, as can be seen from the fact that the corresponding data is either insufficient or non existant. A better understanding of the development of international exchanges implies certainly specific researches about these categories.

\section{Acknowledgements :}

This research was partly financed by the Service d'Etudes Techniques des Routes et Autoroutes (Departement of Transport, convention $n^{\circ}$ 9141019). It has been achieved by a team of the Laboratoire d'Economie des Transports: Frédéric BARDENET, Chantal CHAPLAIN, Lourdes DIAZ OLVERA, Céline GABELLA, Michel LE NIR, Didier PLAT, Charles RAUX and Jean-Louis ROUTHIER.

\section{REFERENCES}

Association Grand-Sud, DTT, CETE Méditerranée et CETE Sud-Ouest. 1989. Trafic autoroutier dans le Grand Sud. Principaux résultats des enquêtes Origines-Destinations réalisées en 1989. Aix-en-Provence, France.

Diaz Olvera, L., Le Nir, M., Plat, D., Raux, C. 1995. Les effets-frontière : évidences empiriques, impasses théoriques. Etudes et Recherches n³. Laboratoire d'Economie des Transports, Lyon, 85p. + annexes

Bröcker, J. 1980. Measuring Trade-Impeding Effects on National Borders by Log-Linear Interaction Analysis. Institut für Regionalforschung, Kiel.

Bröcker, J., Rohweder, H.C. 1990. Barriers to international trade. Methods of measurement and empirical evidence. The Annals of Regional Science, Vol.24, N4, pp.289-305

CETE de l'Est. 1989. Etude du trafic routier transfrontalier au droit de la Plaine d'Alsace. Rapports 1 à 5 et note de synthèse. CETE, Metz, France.

CETE de l'Est. 1991. Recensement de la circulation 1979-1990. CETE, Metz, France.

EUROSTAT. 1991. Transports et Communications - Statistiques annuelles 1970-1989 7C. Commission des Communautés Européennes, Luxembourg

EUROSTAT. yearly. Transports de marchandises : Chemin de fer - Route -Voies navigables intérieures 7C. Commission des Communautés Européennes, Luxembourg

Fabre, F., Klose, A., Somer, G. 1988. COST 305 : Système de données pour l'étude de la demande de transport interrégional de voyageurs. Commission des Communautés Européennes, EUR 10993 FR

Foucher, M., Potel, J.Y. 1993. Le continent retrouvé. DATAR-Editions de l'Aube, Paris

Klaassen, L.H., Wagenaar, S., van der Weg A. 1972. Measuring psychological distance between the Flemings and the Walloons. Papers Reg Sci Assoc, Vol. 29, pp. 45-62 
Maggi, R. 1994. European Integration and the Role of Transport Related Barriers of National Borders. New Borders and Old Barriers in Spatial Development. Avebury, Aldershot

Nijkamp, P., Rietveld, P., Salomon, I. 1990. Barriers in spatial interactions and communications. A conceptual exploration. The Annals of Regional Science, Vol.24, N 4, pp.237-252

Nüsser, H.G. 1989. Effects of frontier impedance factors In Les couloirs Rhin-Rhône dans l'espace européen, edited by Laboratoire d'Economie des Transports, Lyon, pp. 189-212

Portais, M. 1992. Reconversion et nouveaux espaces réticulaires au Mexique. L'Espace Géographique, XXI(3), pp. 231-238

Ratti, R. 1990. The study of the spatial effects of the borders : an overview of different approaches. NETCOM, Vol.4, n¹, pp. 37-50

Ratti, R. 1991. Théorie du développement des régions-frontières. Les cahiers du LERASS, N²4, pp. 9-26

Rey, V. 1991. Borders vs Networks in Eastern Central Europe. Flux, 3, Spring 1991, pp. 21-28

Reynaud, C., Ollivier-Trigalo, M. et Poincelet, M. 1993. Quelle perspective de transport pour l'ouverture à l'Est ?. Recherche Transports Sécurité, 38/39, pp. 36-56

Rietveld, P., Janssen, L. 1990. Telephone calls and communication barriers. The case of the Netherlands. The Annals of Regional Science, Vol.24, N 4, pp.307-318

Rossera, F. 1990. Discontinuities and barriers in communications. The case of the Swiss communities of different language. The Annals of Regional Science, Vol.24, N 4, pp.319-336

Savage, I.R., Deutsch, K.W. 1960. A statistical model of the gross analysis of transaction flows. Econometrica, Vol. 28, N³, pp. 551-572

SETRA. 1982 through 1992. Recensements de la circulation sur les routes nationales et autoroutes (1982 à 1990. SETRA, Bagneux, France.

Szij, E. 1992. Rôle et place de l'Europe dans les échanges internationaux. Cahiers Français, 257, pp. 72-76

\section{APPENDIX: REGRESSION RESULTS}

\begin{tabular}{|l|c|c|c|c|}
\hline Model & I & II & III & IV \\
\hline $\mathrm{R}^{2}$ & 0.926 & 0.934 & 0.962 & 0.935 \\
\hline $\mathrm{R}^{2}$ adj & 0.925 & 0.934 & 0.960 & 0.930 \\
\hline$\beta$ & $2.166(24.29)$ & $2.229(26.16)$ & $1.878(14.34)$ & $2.229(25.47)$ \\
\hline$\chi$ & $-0.0125(-42.08)$ & $-0.0107(-22.29)$ & $-0.0053(-2.92)$ & $-0.0107(-21.70)$ \\
\hline Front & & $-0.692(-4.37)$ & & \\
Front $_{B-F}$ & & & $-1.89(-4.07)$ & \\
\hline Front $_{B-G}$ & & & $-2.54(-5.57)$ & \\
\hline Front $_{B-N}$ & & & $-1.26(-6.03)$ & \\
\hline Front $_{F-G}$ & & & $-3.11(-4.45)$ & \\
\hline Front $_{F-N}$ & & & $-2.55(-3.82)$ & \\
\hline Front $_{G-N}$ & & & $-1.62(-3.31)$ & \\
\hline Front $_{1982}$ & & & & $-0.783(-3.72)$ \\
\hline
\end{tabular}




\begin{tabular}{|l|l|l|l|l|}
\hline Front & & & & $-0.720(-3.42)$ \\
\hline Front & & & & $-0.698(-3.32)$ \\
\hline Front $^{1985}$ & & & & $-0.684(-3.25)$ \\
\hline Front $^{1986}$ & & & & $-0.688(-3.27)$ \\
\hline Front $^{1987}$ & & & & $-0.690(-3.28)$ \\
\hline Front $^{1988}$ & & & & $-0.681(-3.24)$ \\
\hline Front $^{1989}$ & & & & $-0.646(-3.07)$ \\
\hline Front $^{1990}$ & & & & $-0.642(-3.05)$ \\
\hline
\end{tabular}

B:Belgium; F: France; G: Germany;N:the Netherlands In each cell: estimate ( $t$-STAT)

\section{Tests of models}

\begin{tabular}{|l|l|l|}
\hline II against I & $\mathrm{F}_{1,141}=19.09$ & $\mathrm{p}<0.001$ \\
\hline III against II & $\mathrm{F}_{5,136}=19.86$ & $\mathrm{p}<0.001$ \\
\hline IV against II & $\mathrm{F}_{8,133}=0.09$ & not significant \\
\hline
\end{tabular}

